\title{
Peningkatan Kesadaran Hukum Masyarakat di Dusun Sanggrahan II, Desa Muntuk, Kecamatan Dlingo, Kabupaten Bantul, DIY
}

\author{
Dewi Nurul Musjtari ${ }^{1}$, Maesyaroh ${ }^{2}$ \\ 1,2 Universitas Muhammadiyah Yogyakarta
}

\begin{tabular}{|c|c|}
\hline Article History & ABSTRACT \\
\hline \multirow[t]{2}{*}{$\begin{array}{l}\text { Received } 25.06 .2019 \\
\text { Received in revised form } \\
01.10 .2019 \\
\text { Accepted } 05.10 .2019 \\
\text { Available online } 28.10 .2019\end{array}$} & $\begin{array}{l}\text { THE IMPROVEMENT OF COMMUNITY LEGAL AWARENESS IN } \\
\text { SANGGRAHAN II, MUNTUK VILLAGE, DLINGO SUB DISTRICT, BANTUL } \\
\text { DISTRICT, DIY PROVINCE. The formulation of the problem in the community } \\
\text { service activities is how is the process of increasing legal awareness for the } \\
\text { community in Sanggrahan II, Muntuk Village, Dlingo Sub District, Bantul District, } \\
\text { DIY Province. The method used is counseling, training, focus group discussion, } \\
\text { and mentoring. The activity was carried out with the participation of } \\
\text { administrators, the Family Welfare Program group and the community. The } \\
\text { results of this community service activity were that the process of increasing legal } \\
\text { awareness for the community in Sanggrahan II, Muntuk Village, Dlingo Sub- } \\
\text { District, Bantul District, DIY Provine was carried out with } 3 \text { (three) types of } \\
\text { activities including: legal Comuncation on the legal awareness (neighbors and } \\
\text { familylLaw), training for facilitator of the legal awareness and mentoring in } \\
\text { resolving disputes in the community of Sanggrahan II, Muntuk Village, Dlingo } \\
\text { Sub District, Bantul District, DIY Province. }\end{array}$ \\
\hline & KEYWORDS: Community, Improvement, Legal Awareness. \\
\hline
\end{tabular}
Attribution 4.0 International License, which permits unrestricted use, distribution, and reproduction in any medium, provided the original work is properly cited. (c) 2019 Dewi Nurul Musjtari, Maesyaroh.

\section{PENDAHULUAN}

Jumlah penduduk Dusun Sanggrahan II berjumlah 412 orang dengan jumlah kepala keluarga yaitu 117 KK. Penduduk berjenis kelamin laki-laki berjumlah 203 (dua ratus tiga) orang dan berjenis kelamin perempuan berjumlah 209 (dua ratus sembilan) orang. Tingkat pengangguran di dusun Sanggrahan II adalah sebanyak 2\%. Tingkat kelahiran bayi di dusun Sanggrahan II setiap tahunnya adalah 1 sampai dengan 2 bayi. Jumlah anak putus sekolah di Dusun Sanggrahan II terdapat kira-kira 4 orang per tahun. Penyakit yang

\footnotetext{
${ }^{1}$ Corresponding author: Program Studi Ilmu Hukum, Universitas Muhammadiyah Yogyakarta. Jl. Kapten Piere Tendean No.59, Wirobrajan,
} Kota Yogyakarta, Daerah Istimewa Yogyakarta 55252; Email: dewinurulmusjtari@umy.ac.id 
menyebabkan kematian warga mayoritas adalah faktor usia, darah tinggi, jantung, dan stroke. Fasilitas kesehatan dan tenaga medis tidak ada, ada Pendidikan Anak Usia Dini (PAUD), perpustakaan dusun dan kegiatan posyandu yang berjalan setiap bulan sekali.

Potensi warga Dusun Sanggrahan II antara lain adanya kepemimpinan dari Kepala Dusun dan Ibu-ibu PKK yang siap melakukan pemberdayaan masyarakat, adanya dukungan masyarkat dan kemauan untuk berkembang bagi masyarakat. Selain itu adanya tata pemerintahan yang mulai tersusun dan penataan manajemen dusun serta ketersediaan tempat untuk melakukan penyuluhan dan pertemuan antar warga.

Berdasarkan hasil observasi pada pelaksanaan KKN pada Bulan September 2018, Dusun Sanggrahan II belum memiliki tata administrasi pedukuhan yang baik, penomoran rumah secara tersistem, peraturan dusun dan Rukun Tetangga (RT), manajemen keluarga dan kelompok sadar hukum. Namun pada pelaksanaan program KKN sebelumnya telah menghasilkan program penomoran rumah, penyuluhan hidup bersih dan sehat, penyuluhan tentang tanaman obat keluarga dan pembuatan jahe instan. Berdasarkan problematika yang ada dan keberhasilan pada pelaksanaan kegiatan KKN sebelumnya maka pada hasil observasi periode KKN 029 problematika yang mengemuka dan memerlukan solusi adalah adanya konflik keluarga di rumah tangga dan konflik antar warga di masyarakat, belum adanya pengetahuan tentang hukum keluarga dan hukum tetangga. Oleh karena itu agar terjadi keberlanjutan program dan kegiatan pada pelaksanaan KKN PPM yang dilaksanakan pada bulan Januari hingga April maka disusunlah usulan kegiatan kuliah kerja nyata pembelajaran pemberdayaan masyarakat (KKN PPM) ini.

Konsep yang akan digunakan untuk mengatasi permasalahan yang dihadapai masyarakat di Dusun Sanggrahan II adalah membuat program dan kegiatan KKN PPM yang pelaksanaannya akan dilakukan bersama mahasiswa KKN UMY yang akan diterjunkan pada Bulan Januari 2019. Adapun program dan kegiatan yang akan direncanakan antara lain adalah penyuluhan tentang peningkatan kesadaran hukum dengan kegiatan penyuluhan hukum, pelatihan dan pendampingan serta penataan manajemen organisasi kemasyarakatan. Untuk penertiban tata administrasi pemerintahan pedukuhan, penataan perpustakaan dan pengembangan PAUD akan dilaksanakan oleh mahasiswa bersama masyarakat.

Pustaka yang mendukung untuk pelaksanaan program peningkatan kesadaran hukum masyarakat adalah terkait dengan faktor-faktor yang mempengaruhi penegakan hukum di masyarakat. Menurut Soerjono Soekanto, faktor-faktor yang mempengaruhi penegakan hukum, antara lain: faktor hukumnya sendiri, faktor penegak hukum, yakni pihak-pihak yang membentuk maupun menerapkan hukum, faktor sarana atau fasilitas yang mendukung penegakan hukum, faktor masyarakat, yakni lingkungan dimana hukum tersebut berlaku atau diterapkan dan faktor kebudayaan, yakni sebagai hasil karya, cipta dan rasa yang didasarkan pada karsa manusia di dalam pergaulan hidup.

Kelima faktor tersebut di atas saling berkaitan dengan eratnya, oleh karena itu merupakan esensi dari penegakan hukum, serta juga merupakan tolok ukur daripada efektivitas penegakan hukum. Selama ini masyarakat hanya memahami bahwa proses penegakan hukum danya meliputi faktor hukumnya dan faktor penegak 
hukumnya, faktor lainnya seperti sarana dan prasarana, masyarakat dan kebudayaan belum menjadi perhatian mereka.

Oleh karena itulah rangkaian pelatihan yang akan dilakukan termasuk didalamnya memperkenalkan kelima faktor penegakan hukum tersebut kepada masyarakat. Kelima faktor tersebut juga akan disamapikan kepada para calon fasilitator agar lebih memamahi dan mengetahui keterangkaian faktor yang mempengaruhi penegakan hukum.

Di dalam masyarakat permasalahan yang timbul juga terkait dengan berbagai kedudukan dan peranan yang dapat menimbulkan konflik (status conflict dan conflict of roles). Kalau di dalam kenyataan terjadi kesenjangan antara peranan yang seharusnya dengan peranan yang sebenarnya dilakukan atau peranan aktual maka terjadi suatu kesenjangan peranan (role-distance). Masalah peranan dianggap penting karena pembahasan mengenai penegak hukum sebenarnya lebih banyak tertuju pada Diskresi. Diskresi menyangkut pengambilan keputusan yang tidak sangat terikat oleh hukum, dimana penilaian pribadi juga memegang peranan. Di dalam penegakan hukum, diskresi sangat penting, karena:

1) Tidak ada peraturan perundang-undangan yang sedemikian lengkapnya, sehingga dapat mengatur semua perilaku manusia.

2) Adanya kelambatan-kelambatan untuk menyesuaikan perundang-undangan dengan perkembangan-perkembangan di dalam masyarakat, sehingga menimbulkan ketidakpastian.

3) Kurangnya biaya untuk menerapkan perundang-undangan sebagaimana yang dikehendaki oleh pembentuk undang-undang.

4) Adanya kasus-kasus individual yang memerlukan penanganan secara khusus.

Di dalam kehidupan sehari-hari, perangkat dusun akan menghadapi beberapa sikap manusia dengan latar belakang maupun pengalaman masing-masing dengan menujukkan beberapa sikap terhadap hukum antara lain: a) Ada yang taat pada hukum; b) Ada yang pura-pura mentaatinya; c) Ada yang tidak mengacuhkan sama sekali dan ada pula yang dengan terang-terangan melawannya (Dussich, 2015).

Tahapan penyelesaian sengketa menurut pendapat Stevenin dalam Handoko (2001, p. 48) meliputi lima langkah meraih kedamaian dalam konflik (Musnawi, 2014, pp. 41-46). Kelima langkah berikut ini bersifat mendasar dalam mengatasi kesulitan, antara lain:

1) Pengenalan. Kesenjangan antara keadaan yang ada atau yang teridentifikasi dan bagaimana keadaan yang seharusnya. Satu-satunya yang menjadi perangkap adalah kesalahan dalam mendeteksi (tidak mempedulikan masalah atau menganggap ada masalah padahal sebenarnya tidak ada).

2) Diagnosis. Inilah langkah yang terpenting. Metode yang benar dan telah diuji mengenai siapa, apa, mengapa, dimana, dan bagaimana berhasil dengan sempurna. Pusatkan perhatian pada masalah utama dan bukan pada hal-hal sepele.

3) Menyepakati suatu solusi. Kumpulkanlah masukan mengenai jalan keluar yang memungkinkan dari orang-orang yang terlibat di dalamnya. Saringlah penyelesaian yang tidak dapat diterapkan atau tidak praktis. Jangan sekali-kali menyelesaikan dengan cara yang tidak terlalu baik. Carilah yang terbaik. 
4) Pelaksanaan. Ingatlah bahwa akan selalu ada keuntungan dan kerugian. Namun hatihati, jangan biarkan pertimbangan ini terlalu mempengaruhi pilihan dan arah pada kelompok tertentu.

5) Evaluasi. Penyelesaian itu sendiri dapat melahirkan serangkaian masalah baru.Jika penyelesaiannya tampak tidak berhasil, embalilah ke langkah-langkah sebelumnya dan cobalah lagi.

Menurut Bernard Arief Sidharta (2013), kesadaran hukum adalah prosese terbentuknya kaidah-kaidah hukum. Kemampuan membedakan benar-salah, baik-buruk, adil-tidak adil, manusiawi-tidak manusiawi tersebut menyebabkan timbulnya dalam kesadaran manusia keyakinan bahwa dalam situasi konkret tertentu orang seharusnya berperilaku dengan cara tertentu karena hal itu adalah adil. Kesadaran bahwa dalam situasi tertentu orang seyogyanya berperilaku atau tidak berperilaku dengan cara tertentu karena dituntut keadilan disebut kesadaran hukum pribadi. Melalui interaksi antar sesame manusia di dalam masyarakat, lama kelamaan terbentuklah kesamaan perasaan tentang apa yang dirasakan adil atau tidak adil. Tentang apa yang seyogiyanya dilakukan atau tidak dilakukan dalam situsi-situasi tertentu karena hal itu dirasakan adil dan perlu untuk mewujudkan ketertiban dalam masyarakat dan dengan itu terbentuklah kesadaran hukum umum atau kesadaran hukum rakyat (Sidharta, 2013, pp. 8-9).

Munculnya kesadaran hukum didorong oleh sejauh mana kepatuhan kepada hukum didasari oleh indoctrination, habituation, utility dan group identification. Proses itu terjadi melalui internalisasi dalam diri manusia. Kadar internalisasi inilah yang selanjutnya memberikan motivasi yang kuat dalam diri manusia atas persoalan penegakan hukum. Soerjono Soekanto menyatakan terdapat indikator kesadaran hukum masing-masing merupakan suatu tahapan bagi tahapan berikutnya: pengetahuan hukum, pemahaman hukum, sikap hukum, dan pola perilaku hukum (Saifullah, 2010: 105-106).

Berdasarkan uraian yang telah disebutkan di atas maka identifikasi masalah dalam KKN PPM ini antara lain: adanya konflik keluarga di rumah tangga dan konflik antar warga di masyarakat, minimnya pengetahuan masyarakat tentang hukum keluarga dan hukum tetangga. Oleh karena itu agar terjadi keberlanjutan program dan kegiatan maka disusunlah usulan kegiatan kuliah kerja nyata pembelajaran pemberdayaan masyarakat (KKN PPM) ini dengan perumusan masalahnya adalah bagaimanakah proses peningkatan kesadaran hukum bagi masyarakat di Dusun Sanggrahan II, Desa Muntuk, Kecamatan Dlingo, Kabupaten Bantul.

\section{METODE PELAKSANAAN}

Khalayak sasaran pada kegiatan KKN PPM ini adalah kelompok non produktif. Ada dua mitra dalam kegiatan KKN PPM ini, yaitu kelompok pengurus Dusun Sanggrahan II dan kelompok Ibu-ibu PKK di Dusun Sanggrahan II. Pada kegiatan KKN PPM ini juga melibatkan peran serta partisipasi dari 10 (sepuluh) mahasiswa KKN UMY dan masyarakat.

Adapun profil kelompok sasaran dan potensi yang dimiliki sebagai berikut. Dusun Sanggrahan II memiliki seorang Kepala Dukuh dan mempunyai 4 (empat) Ketua RT, disamping itu juga terdapat Badan Permusyawarahan Dusun, Kerohanian Islam dan Karang Taruna, Posyandu, LKMD, BPD, PKK, Kelompok Tani dan Kelompom Pengajian. 
Pelaksanaan program dan kegiatan KKN PPM di Dusun Sanggrahan II, Desa Muntuk, Kecamatan Dlingo, Kabupaten Bantul dengan dilaksanakan di Balai Dusun Sanggrahan II. Metode yang digunakan antara lain: penyuluhan, pelatihan, FGD, dan pendampingan. Kegiatan tersebut dilaksanakan dengan partisipasi dari pengurus dusun, Ibu PKK dan masyarakat.

Adapun langkah-langkah yang dilakukan, antara lain:

1) Penyuluhan tentang "Peningkatan Kesadaran Hukum Masyarakat"

Kegiatan penyuluhan dilakukan dengan langkah-langkah:

a) Persiapan: koordinasi dengan perangkat dusun dan Ibu-ibu PKK, koordinasi dengan mahasiswa KKN, kordinasi dengan peserta penyuluhan, persiapan tempat, tikar, LCD, Laptop dan koordinasi dengan nara sumber.

b) Pelaksanaan: mempersiapkan materi penyuluhan, konsumsi dan sarana-prasarana penyuluhan;

c) Pelaporan: penyusunan laporan pelaksanaan kegiatan dan keuangan.

2) Pelatihan Fasilitator dalam Membentuk Kelompok Sadar Hukum

Pelatihan fasilitasi bagi fasilitator diawali dengan metode ceramah yang dilakukan oleh nara sumber yang berasal dari Fakultas Hukum UMY dan perwakilan bagian Keamanan dan Ketertiban di Desa Muntuk. Adapun langkah-langkah kegiatan pelatihan adalah:

Langkah 1: tahapan persiapan yang dilakukan dengan cara membuat perencanaan kegiatan pelatihan yang dituangkan dalam proposal dan membuat TOR serta surat untuk para pembicara dan undangan bagi peserta pelatihan. Jadwal rangkaian kegiatan pelatihan disusun dengan jangka waktu 8 (delapan) bulan hingga tahapan pelaporan.

Langkah 2: tahapan pelaksanaan kegiatan dilakukan pada bulan kedua setelah penandatanganan kontrak kegiatan pengabdian dengan panduan rundown acara yang dibuat untuk setengah hari. Hal ini dipertimbangkan agar peserta tidak merasa jenuh dan keterserapan materi dilakukan secara bertahap.

Langkah 3: penyusunan hasil diskusi dan pelaporan kegiatan pelatihan serta mempersiapakan acara pendampingan, sharing pengalaman penyelesaian sengketa kemasyarakatan yang dilakukan oleh perangkat desa, dusun maupun ibu-ibu PKK di Dusun Sanggrahan II, Desa Muntuk, Kecamatan Dlingo, Kabupaten Bantul.

3) Pendampingan Kelompok Sadar Hukum

Pendampingan dilakukan dalam rangka menggali praktik fasilitasi yang telah dilakukan di Balai Desa, maupun Balai Dusun dan pada pertemuan Ibu-ibu PKK. Adapun pendampingan dilaksanakan terhadap 40 peserta, 1 nara sumber, 2 panitia. Adapun langkah-langkah pelaksanaan pendampingan sebagai berikut.

Langkah 1: mempersiapkan tempat, ruangan dan peralatan serta undangan bagi peserta.

Langkah 2: pelaksanaan pendampingan dengan tata ruang berbentuk $U$ agar optimalisasi pelaksanaan pendampingan dapat tercapai, pemaparan model fasilitasi dari 
OJK/Lembaga lainnya, perekaman proses pendampingan, eksplorasi pengalaman penyelesaian sengketa melalui fasilitasi.

Adapun materi pendampingan antara lain menyepakati tahapan penyelesaian sengketa dengan materi yang bersumber dari pendapat Stevenin dalam Handoko (2001: 48), terdapat lima langkah meraih kedamaian dalam konflik (Mohamad Musnawi, 2014: 41-46). Apapun sumber masalahnya, lima langkah berikut ini bersifat mendasar dalam mengatasi kesulitan:

a) Pengenalan. Kesenjangan antara keadaan yang ada atau yang teridentifikasi dan bagaimana keadaan yang seharusnya. Satu-satunya yang menjadi perangkap adalah kesalahan dalam mendeteksi (tidak mempedulikan masalah atau menganggap ada masalah padahal sebenarnya tidak ada).

b) Diagnosis. Inilah langkah yang terpenting. Metode yang benar dan telah diuji mengenai siapa, apa, mengapa, dimana, dan bagaimana berhasil dengan sempurna. Pusatkan perhatian pada masalah utama dan bukan pada hal-hal sepele.

c) Menyepakati suatu solusi. Kumpulkanlah masukan mengenai jalan keluar yang memungkinkan dari orang-orang yang terlibat di dalamnya. Saringlah penyelesaian yang tidak dapat diterapkan atau tidak praktis. Jangan sekali-kali menyelesaikan dengan cara yang tidak terlalu baik. Carilah yang terbaik.

d) Pelaksanaan. Ingatlah bahwa akan selalu ada keuntungan dan kerugian. Namun hatihati, jangan biarkan pertimbangan ini terlalu mempengaruhi pilihan dan arah pada kelompok tertentu.

e) Evaluasi. Penyelesaian itu sendiri dapat melahirkan serangkaian masalah baru. Jika penyelesaiannya tampak tidak berhasil, kembalilah ke langkah-langkah sebelumnya dan cobalah lagi.

Langkah 3: penyusunan laporan pelaksanaan pendampingan dan mempersiapkan pembentukan kelompok sadar hukum dan ketahanan keluarga. Deklarasi dan peresmian oleh Pak Kadus.

\section{HASIL DAN PEMBAHASAN}

\section{Penyuluhan tentang "Peningkatan Kesadaran Hukum Masyarakat"}

Kegiatan penyuluhan dilakukan dengan tahapan sebagai berikut.

Persiapan. Tahap persiapan dilakukan pada tanggal 22 Januari 2019. Kegiatan ini dilaksanakan bertepatan dengan kegiatan monitoring I (pertama) kegiatan mahasiswa KKN 029. Pada tahapan ini kegiatan dimulai dengan melakukan rapat koordinasi dengan perangkat dusun, perwakilan Ibu-ibu PKK, mahasiswa KKN, peserta penyuluhan. Selain persiapan tentang kesiapan peserta maka pada tahap koordinasi ini, dilakukan pengecekan kesiapan tempat pelaksanaan, ketersediaan tikar, LCD, Laptop dan konsumsi serta backdrop. Pada rapat koordinasi ini dihadiri sekitar 15 orang. Adapun kegiatan persiapan dapat dilihat pada gambar di bawah ini. 


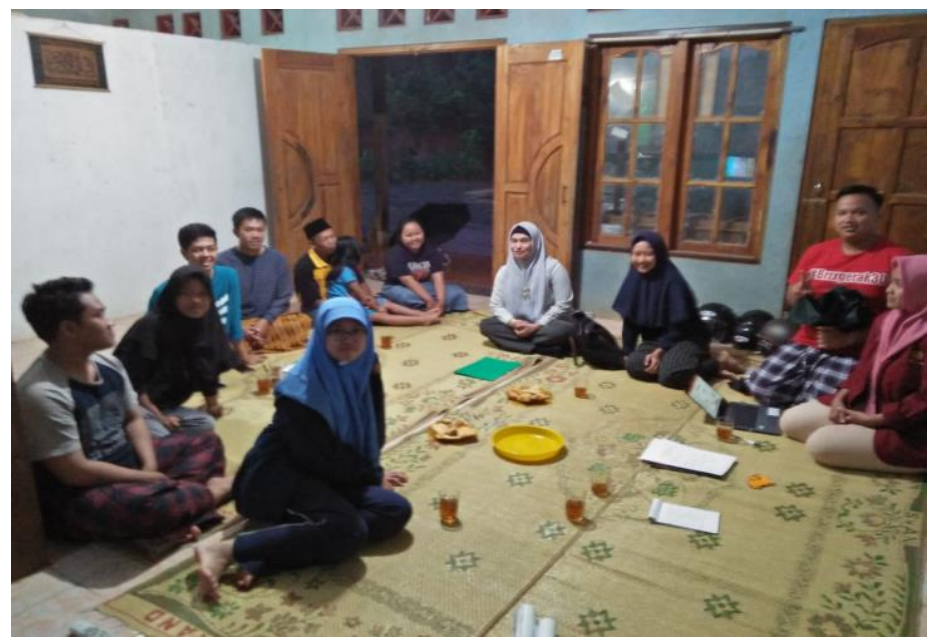

Gambar 1. Persiapan Penyuluhan Hukum Tetangga dan Keluarga

Kegiatan rapat koordinasi yang kedua dilaksanakan pada tanggal 30 Januari 2019. Pada rapat koordinasi ini dihadiri 8 orang. Agdapun agenda rapat adalah persiapan lebih detail terkait dengan susunan acara, pemandu acara, jalannya diskusi, notulensi, dokumentasi, penerima tamu, sie perlengkapan, sie konsumsi. Kegiatan rapat koordinasi kedua dapat dilihat pada gambar di bawah ini.

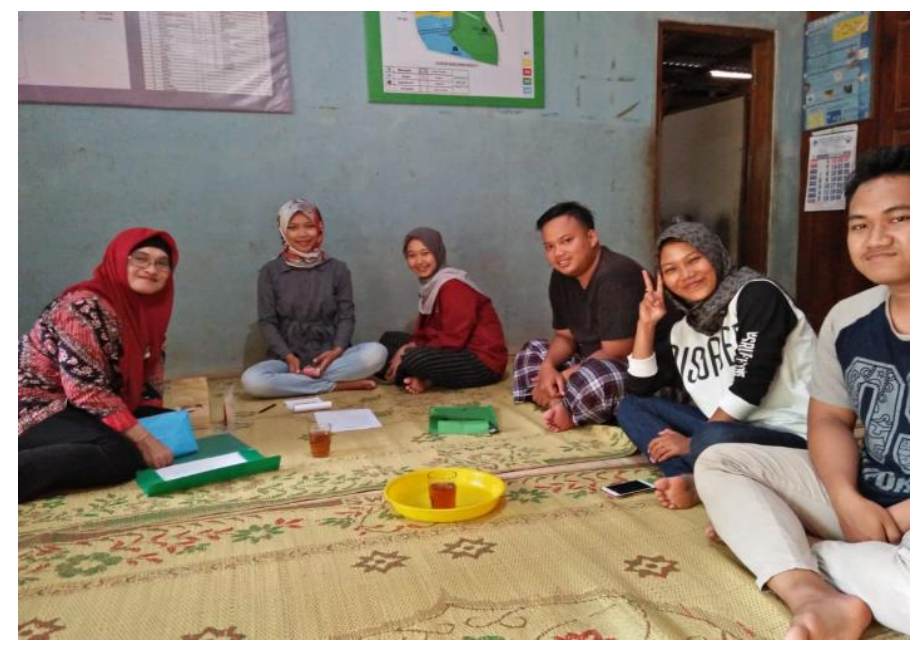

Gambar 2. Rapat koordinasi kedua untuk kegiatan Penyuluhan Hukum Tetangga dan Keluarga

Pelaksanaan. Kegiatan penyuluhan hukum tetangga dan keluarga pada tanggal 7 Februari 2019. Kegiatan ini dihadiri oleh 40 (empat puluh) orang. Kegiatan dimulai pada pukul 20.00 WIB dan berakhir pukul 21.30 WIB. Penyampaian materi tentang Hukum Tetangga dan Hukum Keluarga oleh Dewi Nurul Musjtari. Pemaparan materi berlangsung selama 30 menit. Dilanjutkan dengan diskusi. Pada kegiatan diskusi ini masyarakat aktif bertanya seputar permasalahan yang timbul di masyarakat. Adapun beberapa pertanyaan yang disampaikan antara lain:

1) Apakah kebisingan yang ditimbulkan oleh suara yang timbul dari knalpot milik salah satu warga ada pengaturannya (pasalnya). Jika ada dan telah mengganggu hubungan antara tetangga di Dusun Sanggrahan II, bagaimana cara mengatasi dan apakah ada solusinya? 
2) Jika musim hujan tiba, disatu sisi warga masyarakat senang karena kebutuhan air dapat teratasi. Namun disisi lain ada persoalan yang belum memperoleh solusi terkait dengan adanya genangan air yang penyalurannya tidak lancar dan mulai mengganggu aktivitas hubungan antar tetangga. Untuk mengatasi persoalan tersebut adakah solusinya?

3) Di dalam kehidupan berumah tangga mulai ada percekcokan, baik antara suami dan istri maupun antara orang tua dengan anak. Bagaimana sebaiknya menjaga hubungan suami-istri dalam keluarga dan hubungan antara orang tua dan anak dalam keluarga?

Kegiatan dilanjutkan dengan penjelasan oleh nara sumber. Adapun pada akhir kegiatan kegiatan dilaksanakan Foto bersama antara peserta dan nara sumber. Pelaksanaan kegiatan penyuluhan dapat dilihat pada gambar di bawah ini.

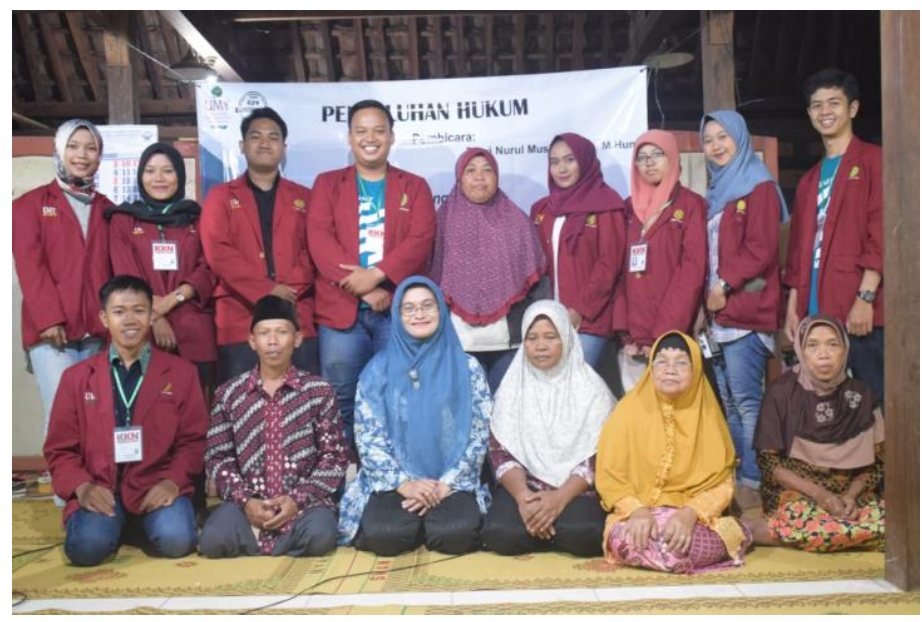

Gambar 3. Kegiatan Penyuluhan Hukum Tetangga dan Keluarga

Pelaporan. Pada tahapan ini dilakukan penyusunan laporan kegiatan dan pendokumentasiannya. Pelaporan dilanjutkan dengan pembuatan berita kegiatan untuk dipublikasikan di Koran Merapi. Selanjutnya artikel dikirimkan ke redaksi Koran Merapi dan dua hari setelah pengiriman maka berita dimuat pada Koran Merapi.

\section{Pelatihan Fasilitator dalam Membentuk Kelompok Sadar Hukum}

Pelatihan fasilitasi bagi fasilitator diawali dengan metode ceramah yang dilakukan oleh Dewi Nurul Musjtari dari Fakultas Hukum UMY. Adapun langkah-langkah kegiatan pelatihan adalah:

Langkah 1: tahapan persiapan yang dilakukan dengan cara membuat perencanaan kegiatan pelatihan yang dituangkan dalam proposal dan membuat TOR serta surat untuk para pembicara dan undangan bagi peserta pelatihan. Jadwal rangkaian kegiatan pelatihan disusun bersama antara pengabdi, mahasiswa dan peserta pelatihan.

Langkah 2: tahapan pelaksanaan kegiatan dilakukan pada tanggal 21 April 2019. Kegiatan dilaksanakan sesuai dengan jadwal yang telah disepakati antara pengabdi, mahasiswa KKN dan peserta pelatihan. Kegiatan dilaksanakan setelah penandatanganan kontrak kegiatan pengabdian dengan panduan rundown acara yang dibuat. Waktu pelaksanaan dengan durasi sejak persiapan hingga penutupan adalah 2 (dua) jam. Hal ini dipertimbangkan agar peserta tidak merasa jenuh dan keterserapan materi lebih optimal. 


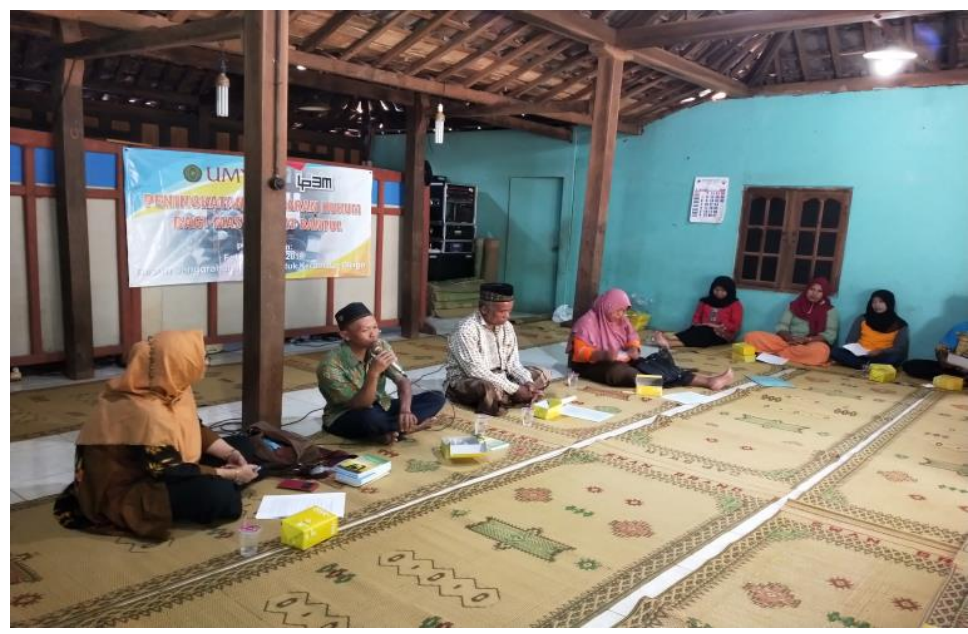

Gambar 4. Kegiatan Pelatihan Bagi Fasilitator Kesadaran Hukum Bagi Masyarakat

Langkah 3: penyusunan hasil diskusi dan pelaporan kegiatan pelatihan serta mempersiapakan acara pendampingan, sharing pengalaman penyelesaian sengketa kemasyarakatan yang dilakukan oleh perangkat dusun maupun ibu-ibu PKK di Dusun Sanggrahan II, Desa Muntuk, Kecamatan Dlingo, Kabupaten Bantul.

\section{Pendampingan Kelompok Sadar Hukum}

Pendampingan dilakukan dalam rangka menggali praktik fasilitasi yang telah dilakukan di Dusun Sanggrahan II dan pada pertemuan Ibu-ibu PKK. Adapun pendampingan dilaksanakan terhadap 40 peserta, 1 nara sumber, 2 panitia. Adapun langkah-langkah pelaksanaan pendampingan sebagai berikut.

Langkah 1: mempersiapkan tempat, ruangan dan peralatan serta undangan bagi peserta.

Langkah 2: pelaksanaan pendampingan dengan tata ruang berbentuk $U$ agar optimalisasi pelaksanaan pendampingan dapat tercapai, pemaparan model fasilitasi oleh nara sumber, perekaman proses pendampingan, eksplorasi pengalaman penyelesaian sengketa melalui fasilitasi.

Adapun materi pendampingan antara lain menyepakati tahapan penyelesaian sengketa dengan materi yang bersumber dari pendapat Stevenin dalam Handoko (2001: 48), terdapat lima langkah meraih kedamaian dalam konflik (Mohamad Musnawi, 2014: 41-46). Apapun sumber masalahnya, lima langkah berikut ini bersifat mendasar dalam mengatasi kesulitan:

1) Pengenalan. Kesenjangan antara keadaan yang ada atau yang teridentifikasi dan bagaimana keadaan yang seharusnya. Satu-satunya yang menjadi perangkap adalah kesalahan dalam mendeteksi (tidak mempedulikan masalah atau menganggap ada masalah padahal sebenarnya tidak ada).

2) Diagnosis. Inilah langkah yang terpenting. Metode yang benar dan telah diuji mengenai siapa, apa, mengapa, dimana, dan bagaimana berhasil dengan sempurna. Pusatkan perhatian pada masalah utama dan bukan pada hal-hal sepele.

3) Menyepakati suatu solusi. Kumpulkanlah masukan mengenai jalan keluar yang memungkinkan dari orang-orang yang terlibat di dalamnya. Saringlah penyelesaian 
yang tidak dapat diterapkan atau tidak praktis. Jangan sekali-kali menyelesaikan dengan cara yang tidak terlalu baik. Carilah yang terbaik.

4) Pelaksanaan. Ingatlah bahwa akan selalu ada keuntungan dan kerugian. Namun hatihati, jangan biarkan pertimbangan ini terlalu mempengaruhi pilihan dan arah pada kelompok tertentu.

5) Evaluasi. Penyelesaian itu sendiri dapat melahirkan serangkaian masalah baru. Jika penyelesaiannya tampak tidak berhasil, kembalilah ke langkah-langkah sebelumnya dan cobalah lagi.

Langkah 3: penyusunan laporan pelaksanaan pendampingan dan mempersiapkan pembentukan kelompok sadar hukum dan ketahanan keluarga. Deklarasi dan peresmian oleh Pak Kadus.

Dalam kegiatan dipraktikkan cara masyarakat mentaati hukum. Berikut ini beberapa cara agar masyarakat mentaati hukum dan dampaknya.

Tabel 2. Beberapa Cara Agar Masyarakat Mentaati Hukum

\begin{tabular}{|c|c|c|c|c|}
\hline No & $\begin{array}{l}\text { Cara Agar } \\
\text { Masyarakat } \\
\text { Mentaati Hukum }\end{array}$ & Tujuan & $\begin{array}{l}\text { Wujud Sikap } \\
\text { Masyarakat }\end{array}$ & Dampak \\
\hline 1. & $\begin{array}{l}\text { Mengetengahkan } \\
\text { sanksi-sanksi } \\
\text { negatif yang } \\
\text { berwujud (coercive) }\end{array}$ & $\begin{array}{l}\text { Ada hukuman } \\
\text { apabila hukum } \\
\text { dilanggar }\end{array}$ & Ketaatan semu & $\begin{array}{l}\text { Masyarakat taat } \\
\text { saat ada petugas }\end{array}$ \\
\hline 2. & $\begin{array}{l}\text { Mengetengahkan } \\
\text { dengan cara lunak } \\
\text { (persuasion) }\end{array}$ & $\begin{array}{l}\text { Agar warga } \\
\text { masyarakat secara } \\
\text { mantap } \\
\text { mengetahui dan } \\
\text { memahami } \\
\text { hukum }\end{array}$ & $\begin{array}{l}\text { Ada persesuaian } \\
\text { dengan nilai-nilai } \\
\text { yang dianut oleh } \\
\text { warga masyarakat }\end{array}$ & $\begin{array}{l}\text { Masyarakat akan } \\
\text { taat dan patuh } \\
\text { pada hukumnya }\end{array}$ \\
\hline 3. & $\begin{array}{l}\text { Mengadakan } \\
\text { penerangan dan } \\
\text { penyuluhan yang } \\
\text { dilakukan berulang } \\
\text { kali (pervasion) }\end{array}$ & $\begin{array}{l}\text { Agar masyarakat } \\
\text { sangant } \\
\text { memahami } \\
\text { terhadap } \\
\text { hukumnya }\end{array}$ & $\begin{array}{l}\text { Mendorong sikap } \\
\text { mentaati dan } \\
\text { melaksanakannya }\end{array}$ & $\begin{array}{l}\text { Menimbulkan } \\
\text { suatu } \\
\text { penghargaan } \\
\text { tertentu terhadap } \\
\text { hukum }\end{array}$ \\
\hline 4. & $\begin{array}{l}\text { Menyudutkan } \\
\text { warga masyarakat } \\
\text { (compulsion) }\end{array}$ & $\begin{array}{l}\text { Warga } \\
\text { masyarakat tidak } \\
\text { punya pilihan lain } \\
\text { untuk mematuhi } \\
\text { hukum }\end{array}$ & $\begin{array}{l}\text { Diciptakan situasi } \\
\text { tertentu }\end{array}$ & $\begin{array}{l}\text { Warga } \\
\text { masyarakat } \\
\text { terpaksa } \\
\text { melakukan atau } \\
\text { tidak melakukan } \\
\text { sesuatu. }\end{array}$ \\
\hline
\end{tabular}

Beberapa yang dipaparkan di atas dimaksudkan agar masyarakat sadar hukum. Menurut Bernard Arief Sidharta (2013), kesadaran hukum adalah prosese terbentuknya kaidah-kaidah hukum. Kemampuan membedakan benar-salah, baik-buruk, adil-tidak adil, manusiawi-tidak manusiawi tersebut menyebabkan timbulnya dalam kesadaran manusia keyakinan bahwa dalam situasi konkret tertentu orang seharusnya berperilaku 
dengan cara tertentu karena hal itu adalah adil. Kesadaran bahwa dalam situasi tertentu orang seyogyanya berperilaku atau tidak berperilaku dengan cara tertentu karena dituntut keadilan disebut kesadaran hukum pribadi. Melalui interaksi antar sesame manusia di dalam masyarakat, lama kelamaan terbentuklah kesamaan perasaan tentang apa yang dirasakan adil atau tidak adil. Tentang apa yang seyogiyanya dilakukan atau tidak dilakukan dalam situsi-situasi tertentu karena hal itu dirasakan adil dan perlu untuk mewujudkan ketertiban dalam masyarakat dan dengan itu terbentuklah kesadaran hukum umum atau kesadaran hukum rakyat (Sidharta, 2013, pp. 8-9).

Munculnya kesadaran hukum didorong oleh sejauh mana kepatuhan kepada hukum didasari oleh indoctrination, habituation, utility dan group identification. Proses itu terjadi melalui internalisasi dalam diri manusia. Kadar internalisasi inilah yang selanjutnya memberikan motivasi yang kuat dalam diri manusia atas persoalan penegakan hukum. Soerjono Soekanto menyatakan terdapat indikator kesadaran hukum masing-masing merupakan suatu tahapan bagi tahapan berikutnya: pengetahuan hukum, pemahaman hukum, sikap hukum, dan pola perilaku hukum (Saifullah, 2010, pp. 105-106).

Pelaksanaan kegiatan pendampingan diakhiri dengan meresmikan pembentukan kelompok sadar hukum di Dusun Sanggrahan II dengan memberikan secara simbolis antara lain materi prosedur penyelesaian sengketa kemasyarakatan, HukumTetangga dan Keluarga, Buku Tuntunan Keluarga Sakinah dan Fiqh Air. Kegiatan pendampinagn dan pembentukan fasilitator kesadaran hukum dapat dilihat pada Gambar 5.

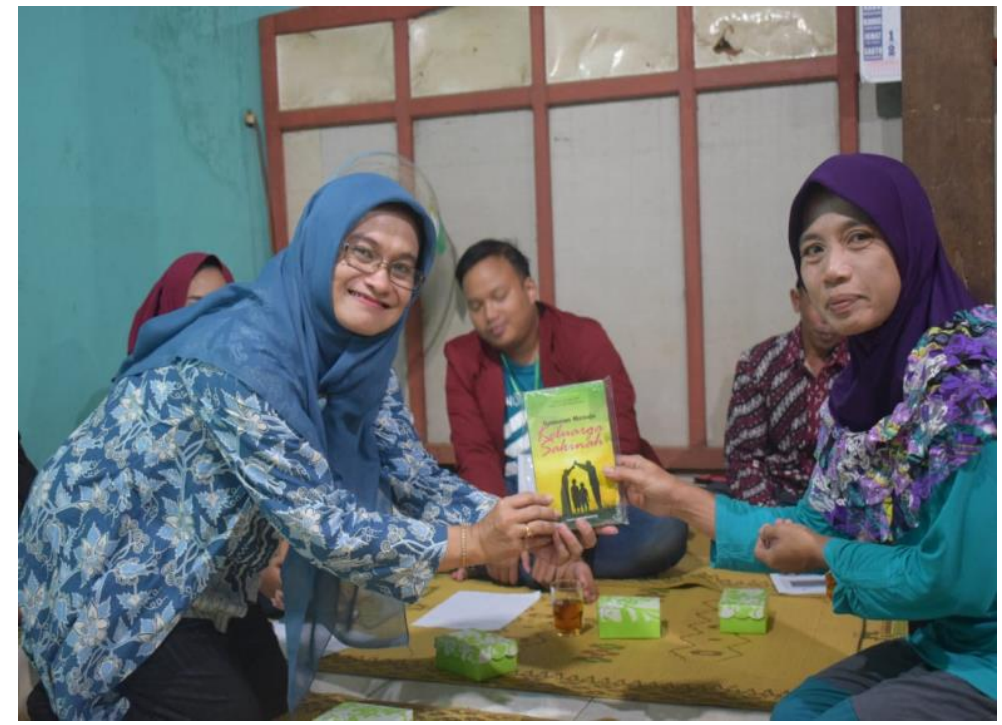

Gambar 5. Penyerahan Buku kepada Fasilitator Kesadaran Hukum Masyarakat

\section{Pembahasan Hasil Pelaksanaan Kegiatan}

Berdasarkan pelaksanaan kegiatan di atas secara keseluruhan kegiatan terlaksana sangat baik dengan adanya dukungan dari mahasiswa KKN 029, pengurus pedukuhan, Ibu-Ibu PKK dan masyarakat dusun Sanggrahan II. Peserta keseluruhan sebanyak 40 (empat puluh) orang sesuai dengan perencanaan kegiatan pada proposal KKN PPM. Adapun hasil pelaksanaan kegiatan dapat dilihat pada Tabel 2. 
Tabel 2. Hasil Pelaksanaan Kegiatan Peningkatan Kesadaran Hukum

\begin{tabular}{|c|c|c|c|c|}
\hline \multirow[t]{2}{*}{ No. } & \multirow[t]{2}{*}{ Kegiatan } & \multicolumn{2}{|l|}{ Kondisi Masyarakat } & \multirow[t]{2}{*}{ Pembahasan } \\
\hline & & Sebelum Kegiatan & Setelah Kegiatan & \\
\hline 1 & $\begin{array}{l}\text { Penyuluhan } \\
\text { tentang } \\
\text { Peningkatan } \\
\text { Kesadaran } \\
\text { Hukum } \\
\text { Masyarakat } \\
\text { (Hukum } \\
\text { Tetangga } \\
\text { dan } \\
\text { Keluarga) }\end{array}$ & $\begin{array}{l}\text { Pengetahuan dan } \\
\text { pemahaman } \\
\text { masyarakat } \\
\text { tentang Kesadaran } \\
\text { Hukum masih } \\
\text { rendah }\end{array}$ & $\begin{array}{l}\text { Ada } 30 \text { anggota } \\
\text { masyarakat mulai } \\
\text { mengetahui dan } \\
\text { memahami } \\
\text { tentang Hukum } \\
\text { dan tumbuh } \\
\text { kesadaran } \\
\text { hukumnya }\end{array}$ & $\begin{array}{l}\text { Ada peningkatan } \\
\text { jumlah orang yang } \\
\text { mengetahui dan } \\
\text { memahami hukum. } \\
\text { Tindak lanjut yang } \\
\text { diharapkan adalah } \\
\text { bahwa dengan } \\
\text { adanya pengetahuan } \\
\text { dan pemahaman } \\
\text { tentang hukum dan } \\
\text { kesadaran hukum } \\
\text { masyarakat maka } \\
\text { diharapkan konflik } \\
\text { yang timbul } \\
\text { dimasyarakat } \\
\text { semakin berkurang. }\end{array}$ \\
\hline 2 & $\begin{array}{l}\text { Pelatihan } \\
\text { Bagi } \\
\text { Fasilitator } \\
\text { Kesadaran } \\
\text { Hukum }\end{array}$ & $\begin{array}{l}\text { Belum ada } \\
\text { masyarakat yang } \\
\text { membudayakan } \\
\text { musyawarah } \\
\text { dengan forum } \\
\text { yang difasilitasi di } \\
\text { tingkat dusun }\end{array}$ & $\begin{array}{l}\text { Perangkat dusun } \\
\text { dan Ibu-ibu PKK } \\
\text { mulai memahami } \\
\text { pentingnya } \\
\text { musyawarah dan } \\
\text { adanya fasilitasi } \\
\text { forum untuk } \\
\text { menemukan } \\
\text { solusi dalam hal } \\
\text { terjadi konflik } \\
\text { antar tetangga } \\
\text { dan keluarga serta } \\
\text { kemasyarakatan. }\end{array}$ & $\begin{array}{l}\text { Diharapkan forum } \\
\text { dan fasilitasi terus } \\
\text { ditingkatkan agar } \\
\text { meminimalisir } \\
\text { persoalan-persoalan } \\
\text { yang terjadi di } \\
\text { masyarakat sedini } \\
\text { mungkin. }\end{array}$ \\
\hline 3 & $\begin{array}{l}\text { Pendamping } \\
\text { an Kelompok } \\
\text { Sadar } \\
\text { Hukum }\end{array}$ & $\begin{array}{l}\text { Belum adan } \\
\text { kelompok } \\
\text { Fasilitator } \\
\text { Penyelesaian } \\
\text { Sengketa antar } \\
\text { Tetangga, } \\
\text { Keluarga dan } \\
\text { Kemasyarakatan }\end{array}$ & $\begin{array}{l}\text { Ada } 20 \text { anggota } \\
\text { masyarakat yang } \\
\text { siap menjadi } \\
\text { fasilitator } \\
\text { kesadaran hukum } \\
\text { masyarakat }\end{array}$ & $\begin{array}{l}\text { Terbentuknya } \\
\text { fasilitator kesadaran } \\
\text { hukum masyarakat } \\
\text { diharapkan dapat } \\
\text { berjalan secara } \\
\text { optimal dan } \\
\text { berkelanjutan. Oleh } \\
\text { karena itu masih } \\
\text { diperlukan } \\
\text { peningkatan } \\
\text { kompetensi dan } \\
\text { ketrampilannya. }\end{array}$ \\
\hline
\end{tabular}




\section{SIMPULAN}

Berdasarkan uraian di atas maka proses peningkatan kesadaran hukum bagi masyarakat di Dusun Sanggrahan II, Desa Muntuk, Kecamatan Dlingo, Kabupaten Bantul dilakukan dengan 3 jenis kegiatan antara lain: Penyuluhan Hukum tentang Kesadaran Hukum (Hukum Tetangga dan Keluarga), Pelatihan bagi Fasilitator Kesadaran Hukum dan Pendampingan dalam penyelesaian sengketa di masyarakat Dusun Sanggrahan II, Desa Muntuk, Kecamatan Dlingo, Kabupaten Bantul. Hasil dari kegiatan peningkatan kesadaran hukum masyarakat bahwa masyarakat di Dusun Sanggrahan II memperoleh tambahan pengetahuan, pemahaman dan ketrampilan tentang kesadaran hukum masyarakat.

\section{REFERENSI}

Dussich, J. P. (2015). The evolution of international victimology and its current status in the world today. Revista de Victimología, (1), 37-81.

Latuconsina, A. (2017). Pentingnya kesadaran hukum dalam bernegara. Retrieved May 15, 2019, from https://mediaharapan.com/pentingnya-kesadaran-hukum-dalambernegara

Machendrawaty, N., \& Safei, A. A. (2001). Pengembangan masyarakat Islam. Bandung: Rosdakarya.

Mas, M. (2014). Pengantar ilmu hukum. Bogor: Penerbit Ghalia Indonesia.

Mertokusumo, S. (2008). Meningkatkan kesadaran hukum masyarakat. Retrieved May 15, 2019, from http://sudiknoartikel.blogspot.co.id/2008/03/meningkatkan-kesadaranhukum-masyarakat.html

Mertokusumo, S. (2007). Mengenal hukum suatu pengantar. Yogyakarta: Liberty.

Muspawi, M. (2014). Manajemen Konflik (Upaya Penyelesaian Konflik dalam Organisasi). Jurnal Penelitian Universitas Jambi: Seri Humaniora, 16(2), 41-46.

Pemerintah Kabupaten Bantul Kecamatan banguntapan, Sarasehan Pengendalian Lingkungan dalam Rangka Mengatasi Konflik Sosial di Masyarakat, Sabtu Legi, 30 Juni 2018 11:02 WIB.

Saifullah. (2010). Refleksi sosiologi hukum. Bandung: Refika Aditama.

Sarwono, B. (2017). Kesadaran Hukum Perlu dibangun dari Keluarga. Retrieved May 15, 2019, from https://www.suaramerdeka.com/smcetak/baca/49580/kesadaran-hukumperlu-dibangun-dari-keluarga

Sidharta, B. A. (2013). Ilmu hukum Indonesia, Upaya pengembangan ılmu hukum sistematik yang responsif terhadap perubahan masyarakat. Yogyakarta: Genta Publishing. 
Jurnal Pengabdian Pada Masyarakat 2019, 4(3), 299-312

Soekanto, S. (2010). Faktor-faktor yang mempengaruhi penegakan hukum. Jakarta: Rajawali.

Soekanto, S. (1982). Kesadaran hukum dan kepatuhan hukum. Jakarta: Rajawali Pers.

Soekanto, S. (1977). Kesadaran hukum dan kepatuhan hukum. Jurnal Hukum $\mathcal{E}$ Pembangunan, 7(6), 462-470.

Yulia, R. (2010). Viktimologi perlindungan hukum terhadap korban kejahatan. Yogyakarta: Graha Ilmu. 